\title{
Persistence of METULA Oil in the Strait of Magellan Six and One-Half Years After the Incident
}

\author{
ERICH R. GUNDLACH, DANIEL D. DOMERACKI and LARRY C. \\ THEBEAU
}

Research Planning Institute, Inc., 925 Gervais Street, Columbia, South Carolina, 29201 USA

\section{INTRODUCTION}

On 9 August 1974, the supertanker METULA (206 $000 \mathrm{dwt}$ ) ran aground just west of the First Narrows in the Strait of Magellan, Chile (Fig. 1). Over the next 1.5 months, until refloating on 25
September, a total of 51500 tons of light Arabian crude and 2000 tons of Bunker $C$ were released. Due to the narrow constrictions of the Strait, much of the oil lost washed onto $65-80 \mathrm{~km}$ of adjacent shoreline (Fig. 1). Since essentially no

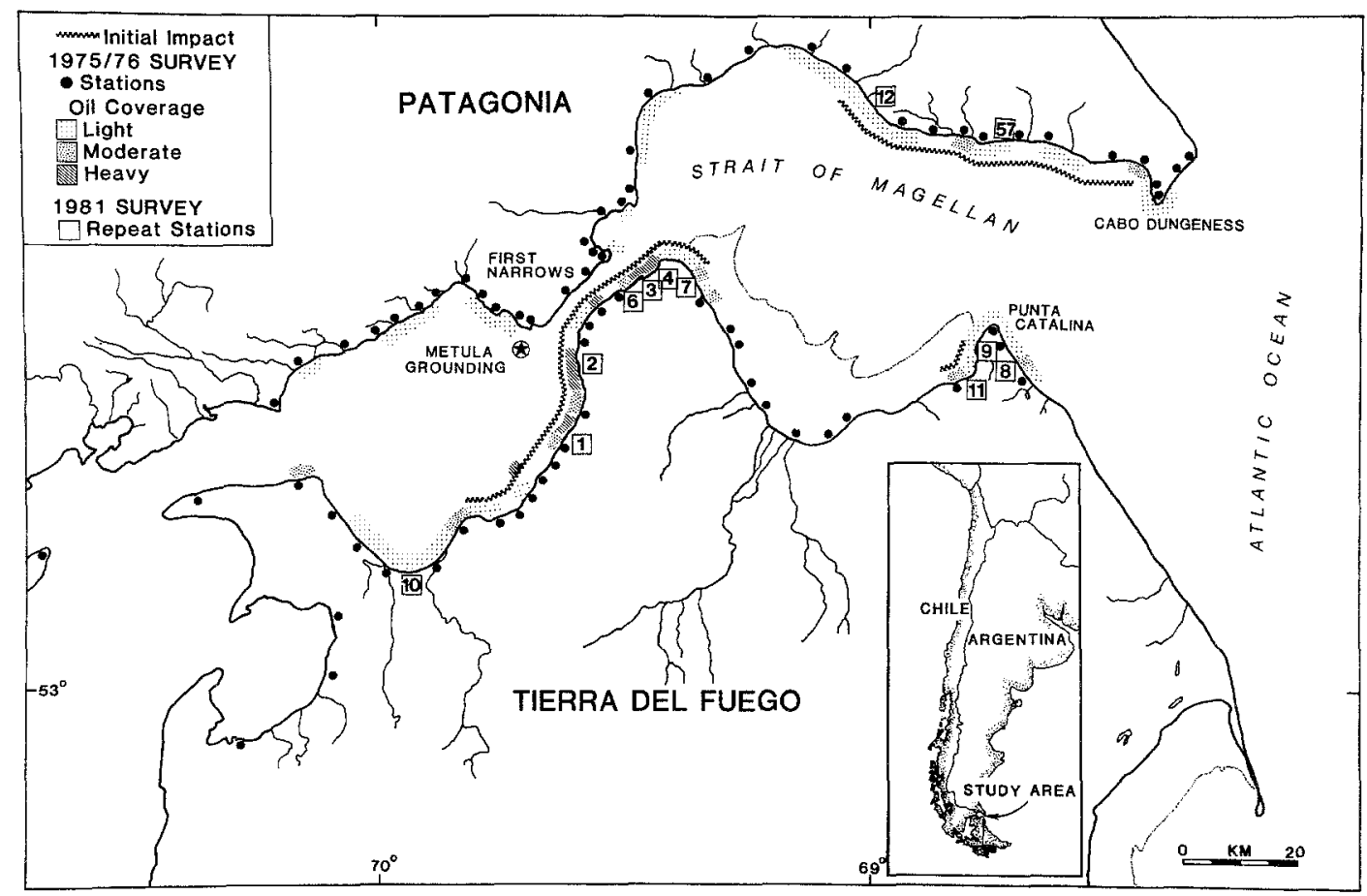

Fig. 1 Location of the METULA oil spill site including station locations, zones of initial impact (August 1974; Hann Jr, 1975), and oil coverage during 1975/76. METULA oil remains most obvious at stations 3, 4 and 6 along the First Narrows. 
cleanup occurred, the METULA spill site remains comparable to a large field experiment in which the long-term, natural degradation of spilled oil can be monitored. The purpose of this paper is to describe the distribution of oil remaining along the Strait of Magellan as of February 1981, and to discuss the physical processes that have influenced the oil's degradation over the last 6.5 years.

\section{PREVIOUS WORK}

Previous reports on the METULA incident have covered a wide range of topics, including details of the grounding and initial shoreline impacts (Gunnerson and Peter, 1976; Hann Jr, 1974, 1975; Hann Jr and Young, 1979), short-term macrobiological effects (Baker et al., 1976; Straughan, 1978) and short-term microbiological changes (Colewell et al., 1978). Folow-up studies, particularly of a heavily oiled marsh site, were undertaken from one to three years after the spill by the Instituto de la Patagonia, the regional scientific institute of southern Chile. Published reports include effects on macrobenthos (Langley and Lembeye, 1977) vegetation (Pisano, 1976; Dollenz, 1977, 1978) and insects (Lanfranco, 1979). An excellent summary of these and other studies, particularly the effects on birds, is presented by Guzman and Campodonico (1980). Investigations of the physical interaction of oil remaining in particular shoreline environments were undertaken with the senior author one to two years after the spill and form the basis of this comparative study. (Hayes and Gundlach, 1975; Blount, 1978).

\section{REGIONAL SETTING}

The climate of the METULA spill site is classified as middle latitude steppe with rainfall averaging 250-350 $\mathrm{mm}$ annually (semi-arid). Daily temperatures range from $3^{\circ} \mathrm{C}$ to $29^{\circ} \mathrm{C}$ in January, and from $-13^{\circ} \mathrm{C}$ to $9^{\circ} \mathrm{C}$ in July. The mean annual temperature is $7^{\circ} \mathrm{C}$. Shoreline ice is not common.

The shoreline of the eastern Strait of Magellan is influenced by its geologic history and impinging physical processes. By far, the most common shoreline type is composed of mixed sand and gravel reworked from adjacent Pleistocene glacial deposits. There is, however, a very large tidal flat composed of Recent fine-grained sediments lo- cated along the south side of the Strait between Punta Catalina and the First Narrows. Tides vary from 6.0 to $10.4 \mathrm{~m}$ east of the First Narrows and from 3.0 to $6.0 \mathrm{~m}$ within the basin between the First and Second Narrows. Tidal currents reach 8 knots within the Narrows. Strong winds, commonly greater than $50 \mathrm{~km} / \mathrm{h}$, blow predominantly from the west $(46 \%)$. Waves generated between the First and Second Narrows may reach several meters in height. The strong winds, high tides, and swift currents of the area played a major role in the initial distribution of oil spilled by the METULA.

\section{METHODS}

This study, undertaken from 18 to 21 February 1981, is based on the resurvey of stations analyzed during August 1975 and February and August 1976 (Hayes and Gundlach, 1975; Blount, 1978). These stations were previously found to contain moderate to heavy concentrations of METULA oil and were considered representative of that shoreline segment. Figure 1 contains the location of all $1975 / 76$ stations as well as those resurveyed during this study.

Comparisons with the data derived during $1975 / 76$ are based on repeat topographic profiling at three sites (where previous reference stakes could be located), and by the analysis of ground-level photographs at seven other sites. At all stations, observations were made of the distribution (length, width, and thickness) of surface oil, and trenches were dug across the beach face to determine the extent of buried, oiled sediment. The physical characteristics (primarily color and consistency) of the remaining oil were noted, and the relationship between substrate (oiled or previously oiled) and resident biological community was given special attention.

\section{RESULTS}

Oil spilled by the METULA in 1974 is still found along much of the southern shoreline of the Strait of Magellan. Environments which remain contaminated include exposed and sheltered mixed sand and gravel beaches, exposed and sheltered tidal flats, and sheltered marshes. Observations are summarized in Table 1 and are discussed below by habitat type. 


\section{TABLE 1}

Summary of observations at stations revisited during the 1981 survey. Oil was most prevalent at stations 3, 4 and 6-all located along the more sheltered First Narrows

\begin{tabular}{|c|c|c|}
\hline $\begin{array}{l}\text { Station number } \\
\text { and location }\end{array}$ & 1975/1976 Survey ${ }^{a}$ & 1981 Survey \\
\hline $\begin{array}{c}1 \\
\text { Punta Remo }\end{array}$ & $\begin{array}{l}\text { A band of surface oil, } 3 \mathrm{~m} \text { wide, is evident along } \\
\text { the upper beach face. Buried, oiled sediment ex- } \\
\text { tends under the surface layer for an additional } 16 \\
\mathrm{~m} \text { seaward. Mousse is evident around the bottom }\end{array}$ & $\begin{array}{l}\text { Oil is limited to an oiled-sediment layer, } 6.2 \mathrm{~m} \\
\text { wide, buried } 5-20 \mathrm{~cm} \text { along the upper beach face. } \\
\text { The middle to lower beach face and the entire } \\
\text { low-tide terrace are free of oil. }\end{array}$ \\
\hline
\end{tabular}

2

Punta Baxa

Puerto Espora
spit and tidal flat

$4 \quad$ Consists of a very heavily oiled marsh (18 ha) and

Espora marsh

6

Punta Espora

7

Cabo Orange

8

Punta Catalina

9

Punta Catalina

10

Southern edge of Bahia Felipe

11 Southeast corner of Banco Lomas tidal flat

12

Cabo Posesion

57

Punta Daniel edges of many cobbles on the low-tide terrace.

Scattered oily debris is evident along the upper high-tide swash lines. Buried, oiled sediment extends for $12 \mathrm{~m}$ along the upper beach face. A laver of asphalted sediment, $35 \mathrm{~m}$ wide and $15 \mathrm{~cm}$ thick, is located along the upper portions of the low-tide terrace.

Very extensive beds of asphalted sediment are located along the interior of the embayment (20-40 $\mathrm{m}$ wide) and along the outer, gently sloping beach face (up to $100 \mathrm{~m}$ wide).

a smaller sheltered tidal flat ( 3 ha). Marsh plants are dominated by Salicornia ambigua and Suaeda argentinensis. Almost all flora and fauna within the heavily impacted zone are killed. An additional 23 ha was lightly oiled but killed most of the resident Suaeda.

Along the active mixed sand and gravel beach in front of the marsh, a buried, oiled-sediment layer, $35 \mathrm{~cm}$ thick, extends for $16 \mathrm{~m}$ along the upper beach face.

To the west of this station, a zone of asphalted sediment, $15-20 \mathrm{~cm}$ thick and $100 \mathrm{~m}$ wide, extends along the upper low-tide terrace.

Tar balls are common along the upper swash lines and oil-stained cobbles appear across much of the beach face. Extensive deposits of asphalted sediment intermittently appear as pockets of clean gravel migrate from west to east along the beach.

Oil-stained gravel is common along the upper swash lines. An asphalted-sediment pavement, $20 \mathrm{~m} \times$ $150 \mathrm{~m}$, is present along the upper low-tide terrace.

Consists of a washover along the Atlantic coast which has several buried, oiled-sediment layers and a surface of asphalted sediment along the crest of the upper beach face.

Small pieces of asphalted sediment are scattered across the upper beach face (located along the west side of the spit).

Pieces of asphalted sediment are present on top of the spit that fronts the area. Behind this spit, narrow discontinuous bands of asphalted sediment line the upper edges of the channel.

A discontinuous band of thin oil with scattered tar balls is present along the very upper edge of this huge tidal flat.

Scattered oily debris is found along the upper swash lines.

Scattered oil crust is found along upper berm area. Lightly scattered, oiled-sediment conglomerates are on the upper low-tide terrace.
METULA oil remains visible as oil-clumped sand along the beach face, and as small scattered patches of oiled-sediment pavement on the low-tide terrace. The lower portion of the low-tide terrace now supports extensive mussel beds.

The interior and exterior zones of asphalted pavement show only minor patchy signs of erosion, particularly along the upper edges.

The marsh shows only minor signs of recovery, particularly a $10-30 \mathrm{~cm}$ regrowth of Salicornia along the upper oiled fringe.

Buried, oiled sediment, now composed of hard asphalt, remains present along $2.5 \mathrm{~m}$ of the upper berm.

A zone of asphalted pavement, $90-100 \mathrm{~m}$ wide, remains along the upper low-tide terrace.

Asphalted sediment still remains, having a maximum dimension of $40 \mathrm{~m} \times 5 \mathrm{~m}$ and a thickness of $15 \mathrm{~cm}$. No other METULA oil is present; however, some light, oily swashes of recently spilled oil are common along the upper beach face.

No surface or buried oil remains along the beach face or low-tide terrace.

This site has been extensively eroded. No oil could be found.

No oil remains at this site.

No oil remains on the spit; however, the narrow bands of asphalted sediment along the interior margin still persist.

Oil remains just as it was previously. A vehicle has driven over the site leaving tracks across the oiled area.

No oil is present.

No oil is visible.

${ }^{a}$ Annual data not available. 

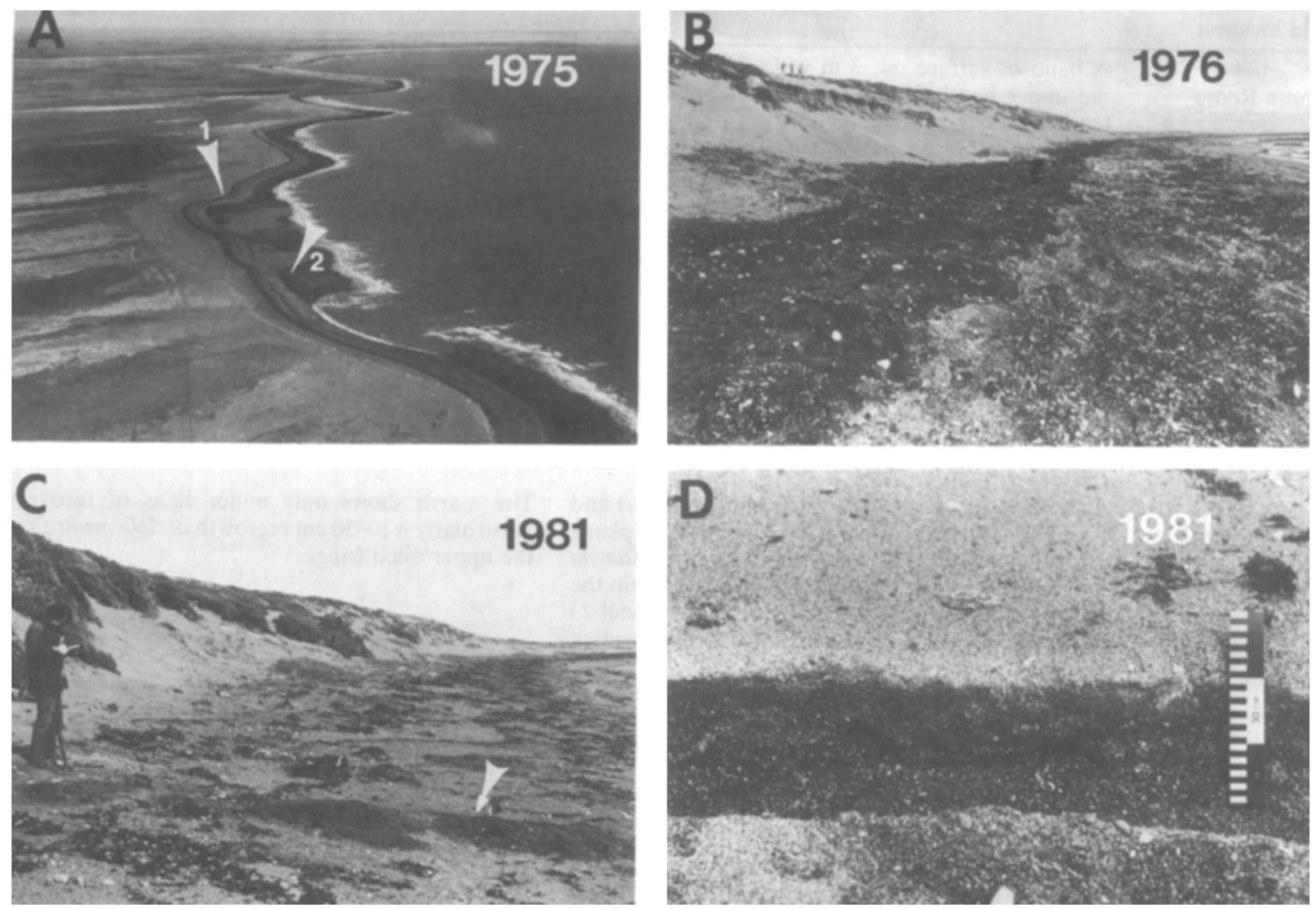

Fig. 2 Photographs of the Punta Remo area (station 1). (A) Aerial view from 18 August 1975. Arrow 1 indicates oil along the upper beach face; arrow 2 points to asphalted sediment along the low-tide terrace. (B) Ground view of station 1 on 9 February 1976. Oiling extended $3 \mathrm{~m}$ across the surface and penetrated $5 \mathrm{~cm}$ into the sediment. Buried layers of oiled sediment extended an additional $16 \mathrm{~m}$ down the beach face. (C) The upper beach face at station 1 on 20 February 1981. No oil is present on the beach face, but oiled sediment remains present 5-20 cm below the surface along a zone $6.2 \mathrm{~m}$ wide. Arrow indicates location of Fig. 2D. (D) Close-up of loosely packed, oiled sediment lying below the surface at station $1(20$ February $1981 ;$ scale $=30 \mathrm{~cm})$.

\section{MIXED SAND AND GRAVEL BEACHES}

\section{Exposed Beaches}

The majority of the shoreline impacted by the METULA consists of exposed mixed sand and gravel beaches. during the 1975/76 survey, remaining oil was classified into light, moderate, or heavy coverage (Fig. 1). Lightly oiled areas contained scattered, asphalted-sediment fragments; moderate coverage commonly contained an oiled-sediment pavement at least $1 \mathrm{~m}$ wide, while heavy coverage encompassed an oiled zone greater than $3 \mathrm{~m}$ wide. By 1981, most areas that had previously been lightly to moderately oiled were clean. Wave activity, causing shoreline erosion (particularly at station 8 ) or sediment reworking (e.g. stations 7, 9, 12, 57, and the exposed portion of station 10), was the primary cleansing process. Sites that still contained major quantities of oil in 1981 are located at station 1 (Punta Remo) and along the First Narrows (stations 3,4 , and 6 ).

Station 1 is located along a stable portion of shoreline exposed to waves generated by the westerly winds crossing the embayment between the First and Second Narrows. At the time of the spill in 1974 , the entire intertidal zone was covered by thick accumulations of oil. During our first survey in August 1975, one year after the 

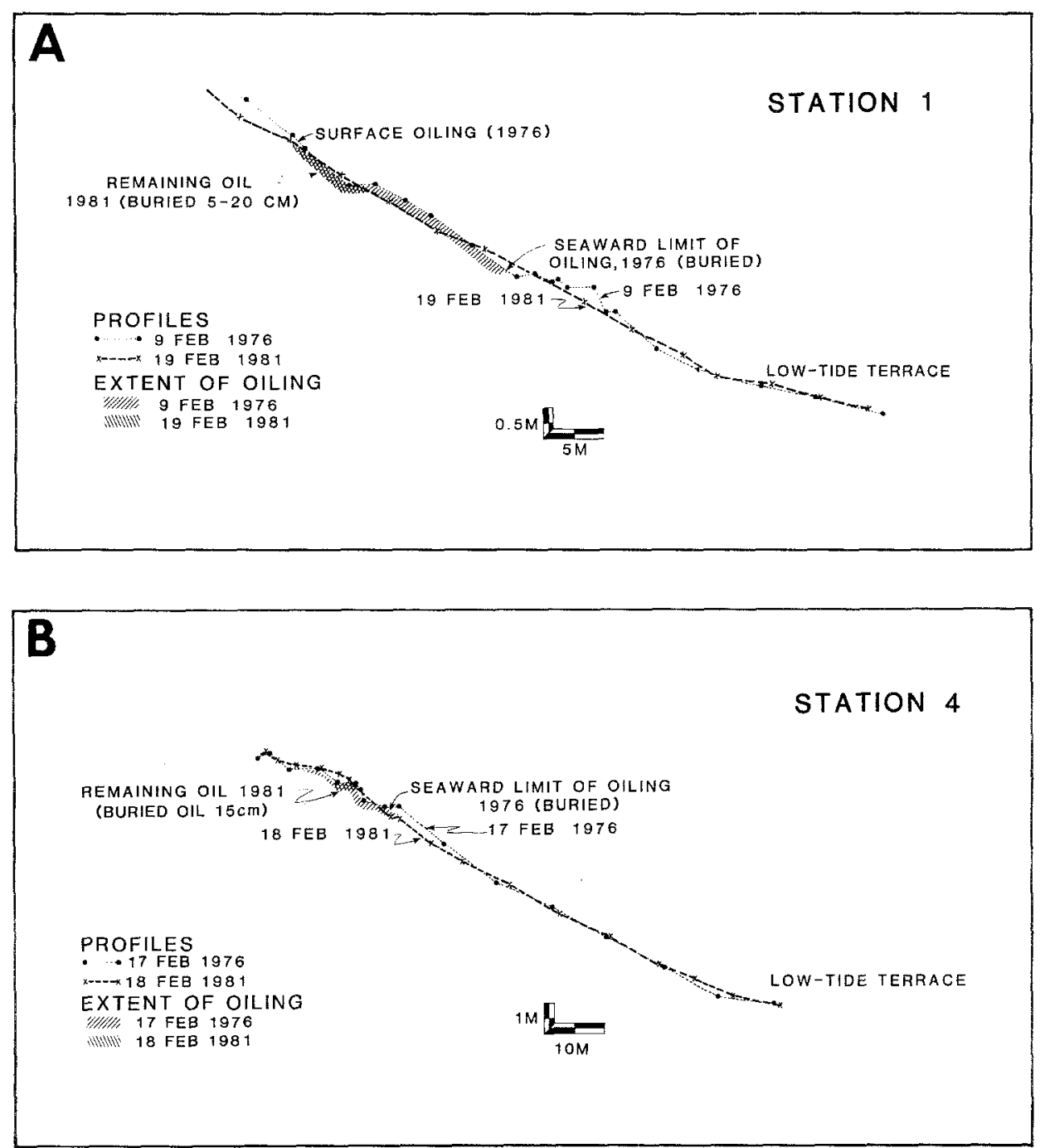

Fig. 3 (A) Comparative profiles (1976 and 1981) of station 1. Surface oil present in 1976 was buried by 1981, so the beach face appears clean. Below the surface, oiled-sediment layers were reduced from $19 \mathrm{~m}$ to $6.2 \mathrm{~m}$. Wave action reworked most of the mid beach face sediments and removed the oil from this zone. (B) Comparative profiles (1976 and 1981) of station 4 along the First Narrows. In 1981, rock-hard asphalted sediment remains buried in a $2.5 \mathrm{~m}$ zone along the upper beach face. Wave energy is generally low in this area.

spill, oiled sediment remained obvious as a $3 \mathrm{~m}$ band along the upper beach face (Fig. 2A,B) and as several buried layers extending another $15 \mathrm{~m}$ seaward to the mid beach face. By February 1981, no surface oil was visible; however, a $6.2 \mathrm{~m}$ zone of loosely packed, oiled sediment remained 5-20 $\mathrm{cm}$ below the surface (Fig. 2C, D). As indicated by the analysis of comparative beach profiles
(Fig. 3A), the oiled zone is in the same position along the upper beach face as the original surface layer. Buried oil that previously extended to the mid beach face was reworked and eliminated over the intervening years. In total, the width of the oiled zone was reduced from $19 \mathrm{~m}$ to $6.2 \mathrm{~m}$.

The beach at station 4, located along the First Narrows, shows a pattern of oil degradation sim- 

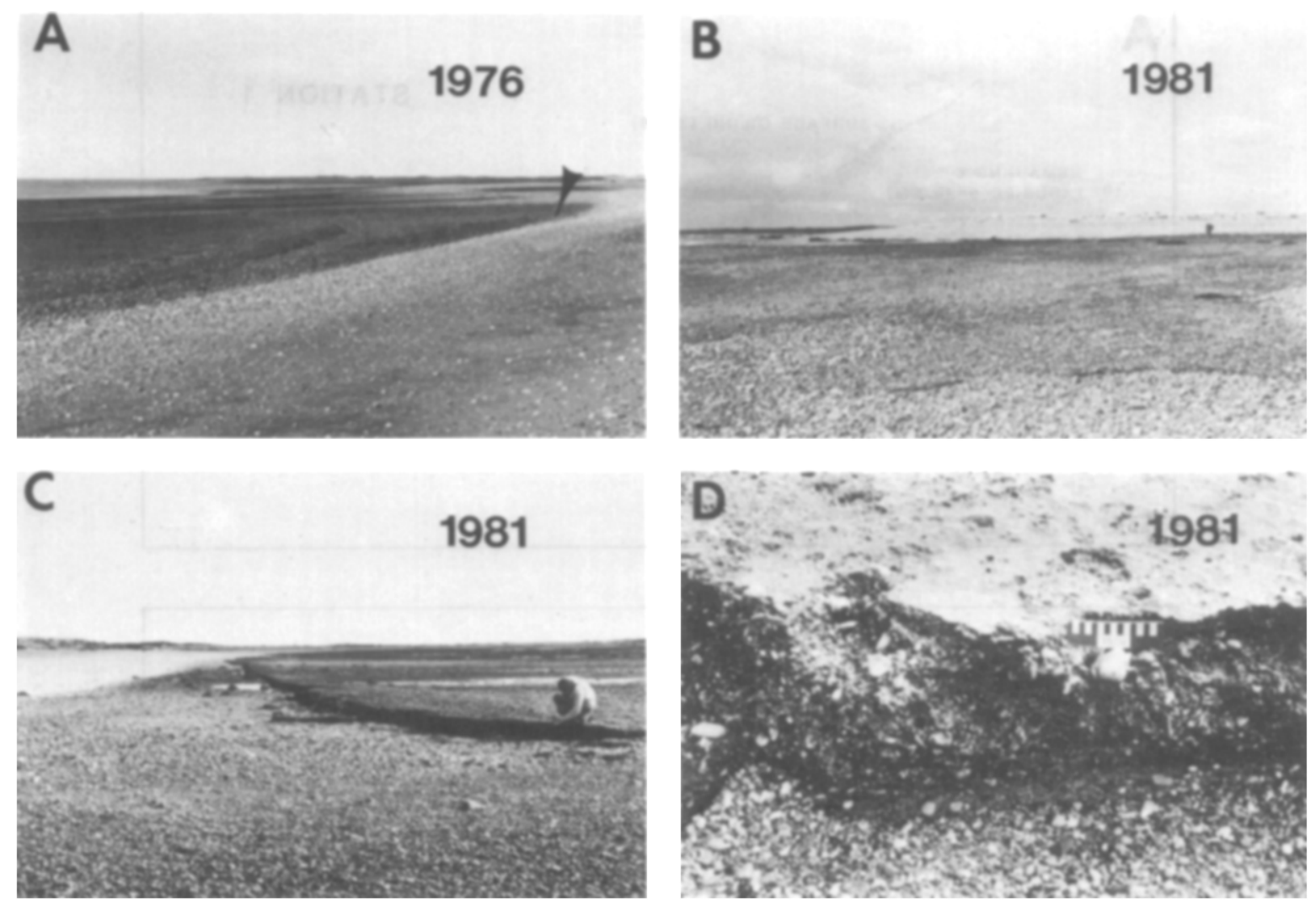

Fig. 4 Views of the asphalted-sediment pavement located along the lower beach face and upper low-tide terrace along the First Narrows. (A) View along the exposed side of Puerto Espora spit (station 3) on 12 February 1976. Arrow indicates the upper boundary of asphalted sediment. (B) Same area as 4A on 20 February 1981. More loose gravel is on the surface of the pavement than in 1976; however, there was little erosion of the pavement. (C) Ground-level view $100 \mathrm{~m}$ west of Espora marsh entrance on 20 February 1981. (D) Close-up of the eroding upper edge of the asphalted-sediment pavement on 20 February 1981 (scale $=15 \mathrm{~cm}$ ). Maximum measured oil concentrations reached ten per cent (Blount, 1978). In many places, brown mousse remains in the center of these thick deposits.

ilar to that of station 1 . In this case, oiled sediment was originally buried along the upper $16 \mathrm{~m}$ of beach face (Fig. 3B). By 1981, a $2.5 \mathrm{~m}$ band of rock-hard asphalted sediment could still be found.

In addition to the beach face, substantial quantities of METULA oil were deposited along the low-tide terrace portion of the shoreline, particularly on the south side of the Strait between the First Narrows and station 1 (Fig. 2A). In 1975/ 76 , oil could still be observed under the cobbles at station 1 and as thick asphalted sediment at stations 2, 3, 4 and 7. The widths of these deposits ranged from $10 \mathrm{~m}$ to over $100 \mathrm{~m}$. By 1981, the low-tide terraces at stations 1,2 , and 7 were completely free of oil. Stations 3 and 4 , which continued to show extensive terrace oiling, were in the zone of heaviest initial impact. Both stations are located along the south side of the First Narrows-an area of high currents but low wave activity. At each site, the $10-20 \mathrm{~cm}$ thick deposits of asphalted sediment had degraded little since 1975 (Fig. 4A-C). In several places, these asphalted-sediment pavements extend to widths of over $100 \mathrm{~m}$. Brown mousse remains visible inside many of the thicker deposits, and gravel is commonly scattered across much of the pavement's surface. The primary area of degradation 

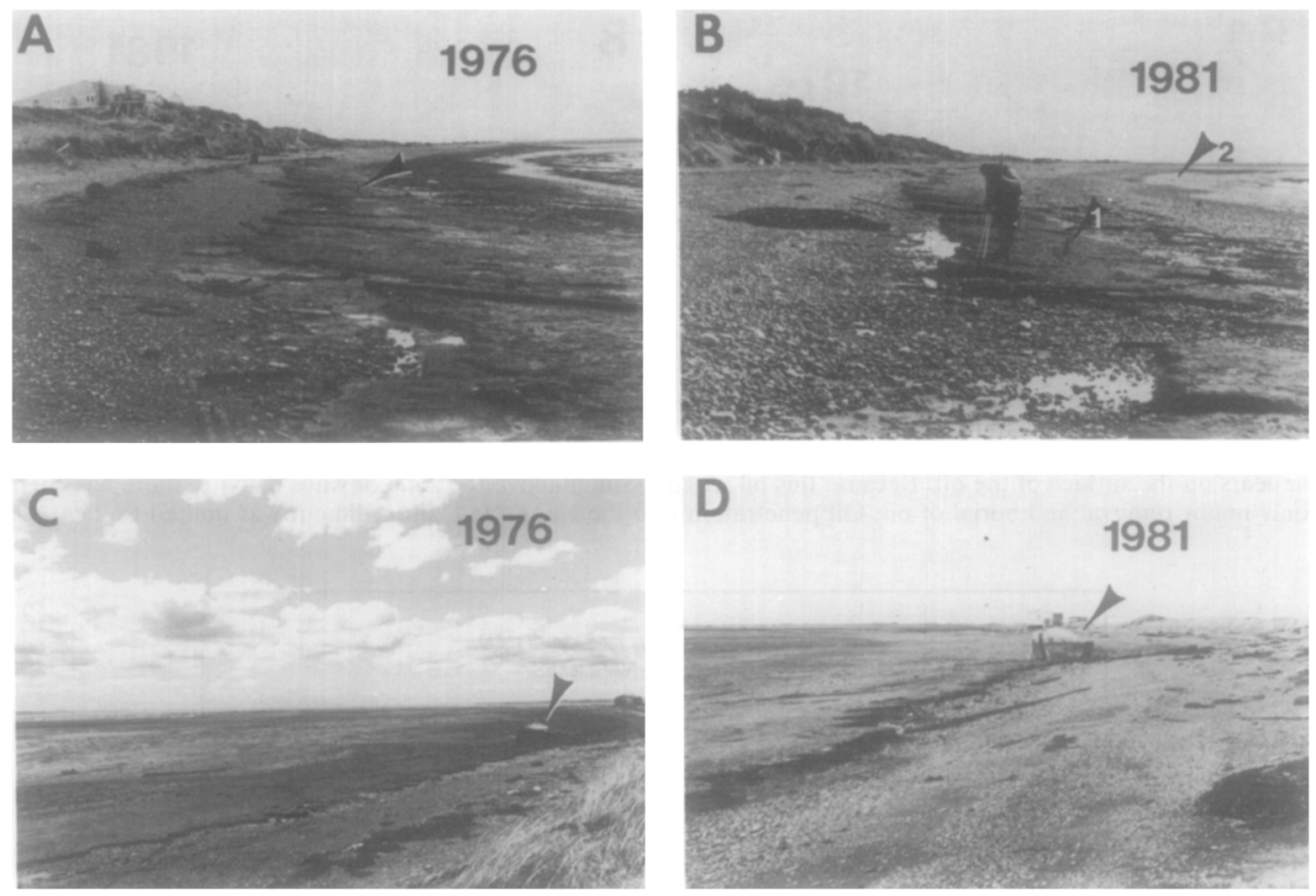

Fig. 5 Ground-level views of asphalted-sediment pavement along the interior, sheitered mixed sand and gravel beach at station 3 at Puerto Espora. (A) View facing west on 16 August 1976. Arrow indicates stake visible in Fig. 5B. (B) West-facing view on 19 February 1981. Arrow 1 marks same stake as Fig. 5A. Only minor erosion of the pavement has occurred over the intervening 4.5 years. There was no physical degradation at all of the oiled-sediment pavement in the southwest corner (arrow 2) of this area. (C) View facing east on 12 February 1975. Arrow indicates block also present in Fig. 5D. (D) Same view as Fig. 5C on 20 February 1981. Only minor erosion has occurred along the upper edge of the asphalted-sediment pavement in this sheitered area.

is located along the most landward edge of the pavement where waves have caused an erosional scarp (Fig. 4D). In some cases, the pavement is undercut which increases the erosion rate.

The biological community varies greatly in this area as it does throughout the Strait region. Patchy but densely populated mussel beds are common along the lowest portion of the intertidal zone. During the spill, there was complete destruction of the biological community where thick accumulations covered these beds; however, the distribution of the marine flora and fauna in the Strait is so patchy as to make extrapolation to all impacted areas impossible. In the First Narrows, extensive mussel beds continue to be present along the lower intertidal zone, and in several areas algae are now attached to gravel on top of the pavement surface. In areas that were heavily impacted and are now free of oil, particularly station 2, there has been a tremendous repopulation of the area by mussels. Long-term biological studies by the Instituto de la Patagonia also indicate an increase in populations over those found after initial impact (Guzman and Campodonico, 1980).

\section{Sheltered Beaches}

Almost all the beaches of the spill site are ex- 

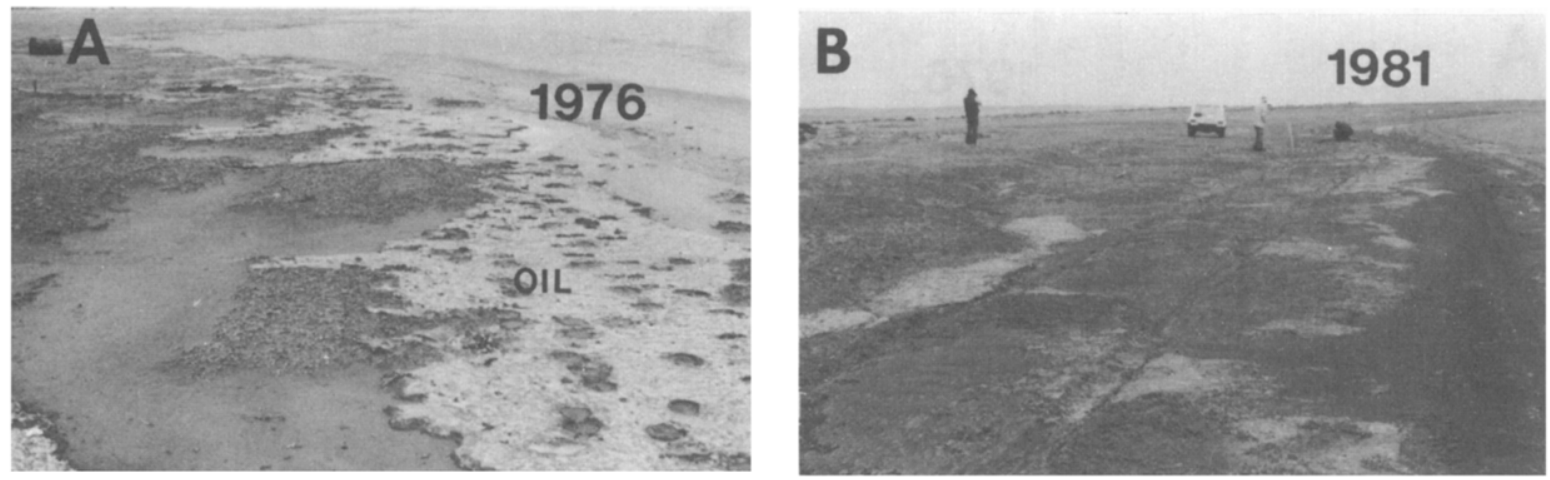

Fig. 6 Views of oil remaining along the upper swash lines of the enormous tidal flat located between Punta Catalina and the First Narrows (station 11) on (A) 16 August 1976 and (B) 18 February 1981. A light, silt crust appears on the surface of the oil. Because this oil was deposited above the zone of wave activity, there has been only minor removal and burial of oil. Oil penetration into the compacted, silt sediment was limited to $2 \mathrm{~cm}$.

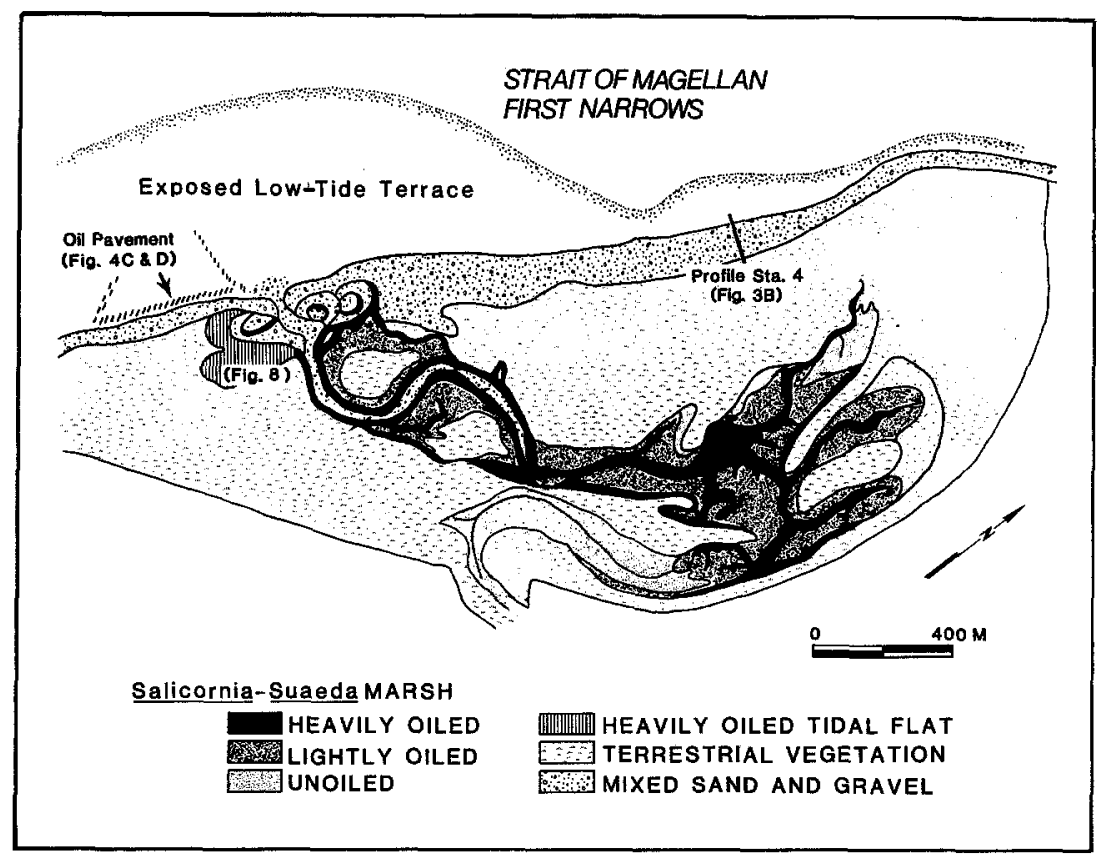

Fig. 7 Plan view of the Espora marsh area indicating the extent of oiling. Figures 8 and 9 contain aerial and ground views of the marsh. In total, 18 ha of marsh and 3 ha of tidal flat remain heavily oiled and totally destroyed. An additional 23 ha were lightly oiled (only Suaeda was killed).

posed to waves; however, at stations 3 and 10 , a spit shelters the interior beaches of mixed sand and gravel. Station 3, along the First Narrows at Punta Espora, was heavily impacted and serves to illustrate oil interaction within this shoreline type. Because there is very little wave activity behind the spit, there has been almost no change in the overall condition of oil in this area. An asphalted-sediment pavement, $15 \mathrm{~cm}$ thick and $20-40 \mathrm{~m}$ wide, extends along the entire landward 

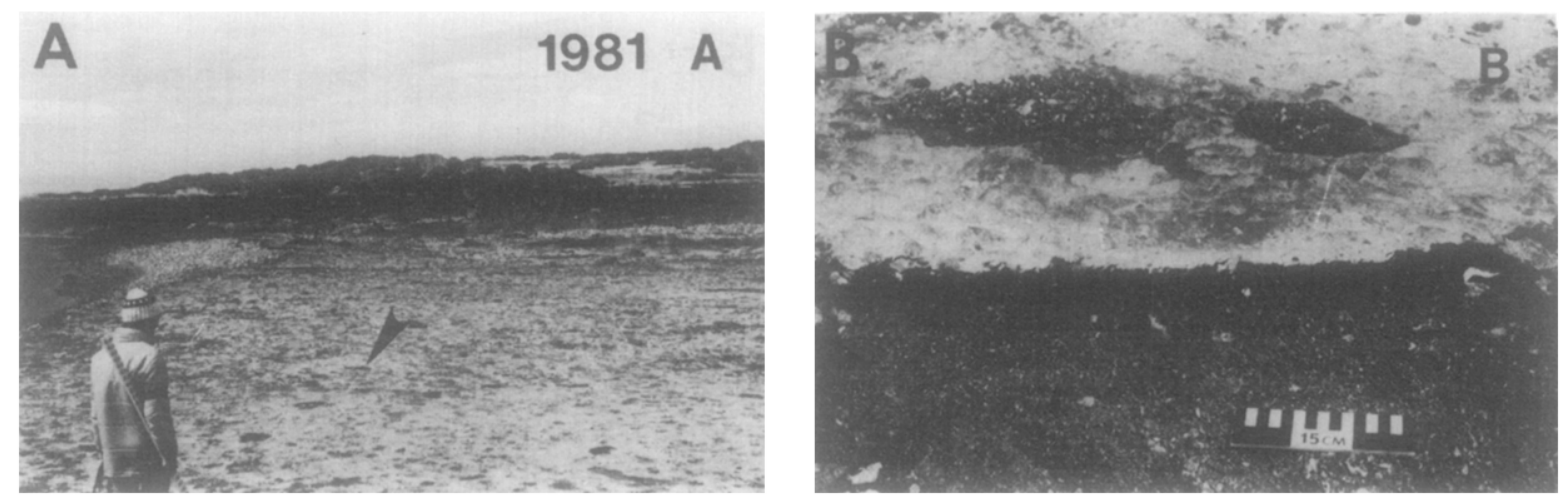

Fig. 8 Ground-level view (A) and close-up (B) of the heavily oiled tidal flat at the entrance to Espora marsh. Arrow indicates location of close-up photograph. Sediment is oiled to a depth of $5 \mathrm{~cm}$.

edge of the embayed area. Differences between $1975 / 76$ and 1981 are limited to some minor erosion along the upper edge of the pavement (Fig. 5A-D). In the more sheltered, southwest corner of this area, there has been virtually no change at all. In fact, the deposited oil still remains very soft and mousse-like in consistency.

\section{TIDAL FLATS}

Both exposed and sheltered tidal flats were impacted by oil spilled by the METULA, although major impacts were limited to two relatively small, sheltered tidal flats located along the First Narrows.

\section{Exposed Flats}

The south side of the eastern Strait of Magellan contains an enormous tidal flat $(10 \mathrm{~km} \times 40 \mathrm{~km})$ composed of fine-grained sand and mud. During the spill, a small amount of oil skimmed over the hard surface of the flat and beached along the spring-tide swash lines in the southeast corner of the area (Fig. 1). Since this oil was deposited above the zone of wave action, it has changed little over the intervening years (Fig. 6A, B). Oil did not sink deep into the sediment due to the impermeable nature of the substrate, but remains only on the upper $2 \mathrm{~cm}$ of the flat surface.

\section{Sheltered Flats}

The METULA spill site provides two examples of impacted, sheltered tidal flats. One is located behind the Puerto Espora spit on the south side of the First Narrows as discussed under sheltered mixed sand and gravel beaches; the other is at a site called Espora marsh (Fig. 7). The tidal flat located at the entrance to Espora marsh was heavily oiled during the spill. By 1981, there was no indication of recovery. A hard, $5 \mathrm{~cm}$ thick, asphalted-sediment pavement covered most of the 3 ha of tidal flat surface (Fig. 8A, B). The presence of a very thin layer of clay on the pavement surface, deposited over the last 6.5 years, illustrates the extremely low rate of sedimentation in the area.

\section{MARSHES}

The Espora area also provides an example of a heavily oiled marsh system. During the spill, accumulations were very heavy, primarily concentrated along the channel margins and along the upper edges of the marsh (Figs 7A, 9A). Pools of oil ranged up to $30 \mathrm{~cm}$ deep. Dominant vegetation types damaged by the spill were Salicornia ambigua (saltwort) and Suaeda argentinensis (sea blite). In 18 ha of heavily oiled marsh, almost all vegetation was killed. In the topographically lower central portions of the flat, oil generally floated over the Salicornia, but oiled and killed the higher-standing Suaeda. This area was considered to be lightly oiled and encompassed 23 ha. A third vegetation type, Lepidophyllum, is found above the high water mark and was not greatly affected by the oil. Assuming a $5 \mathrm{~cm}$ average depth of oil over all heavily oiled areas, this produces an estimate of 9000 tons of mousse that entered this marsh during the initial phases of the spill.

During the 1981 survey, very little overall recovery of the marsh was noted (Fig. 9B, C). 

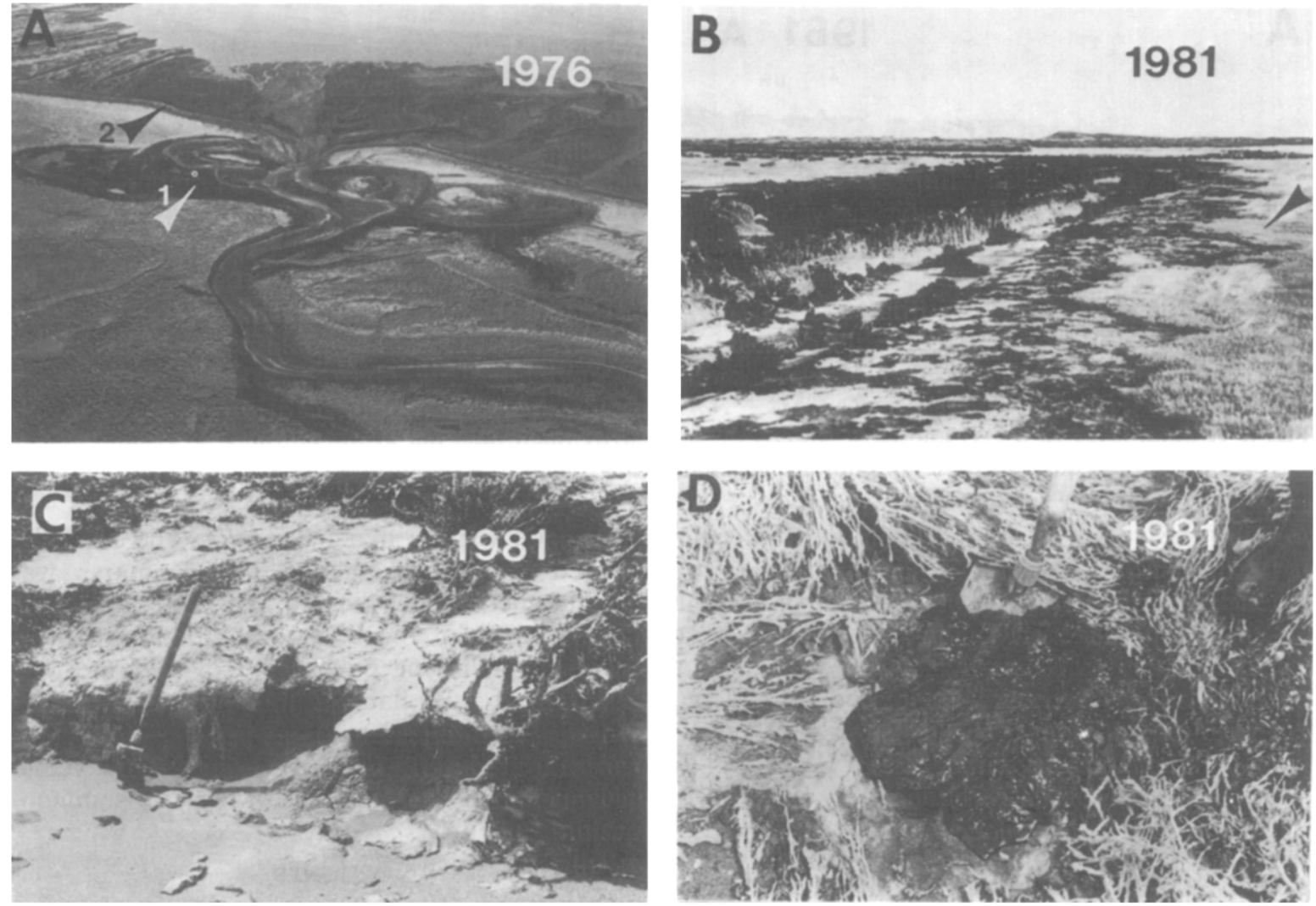

Fig. 9. Views of the heavily oiled marsh at Espora 'station 4) along the First Narrows. (A) Overview of the marsh entrance on 9 March 1976. Arrow 1 indicates the location of the oiled tidal flat in Fig. 8. Arrow 2 indicates the asphalted-sediment pavement in Fig. 4C, D. (B) Black and white, infrared photograph of the heavily oiled channel margin on 19 February 1981. Live Salicornia is illustrated by arrow. (C) Thick oil coating along channel walls of the marsh. Note that the hardened oil maintains its integrity even though the wall is being undercut. (D) Common view of the remaining oil pools present on the marsh. The color of the oil is black with brown (mousse) streaks.

Heavily oiled channel edges looked as they did previously. In many places, thick mousse deposits of brown color and soft consistency were still evident (Fig. 9D). Only Salicornia located along the upper channels showed some $10-30 \mathrm{~cm}$ of new lateral growth extending out over the deposited (and still soft) oil. Roots of these new plants, however, did not extend into the oil, but were limited to entry into the dead material above the oil. So, it appears that Salicornia at Espora marsh is able to cover the oily surface only when it has a base of previously killed plant material (Fig. 10). The other primary vegetation type, Suaeda did not show recovery in the oiled areas. The reasons for the lack of recovery noted at
Espora marsh are seemingly related to the thickness of the deposited oil and the lack of degradation processes.

The coating of oil in the marsh area also influences channel morphology. Based on a review of photographs taken in the same area, there has been no increase in the extent of slumping along the smaller marsh channels. It appears that the $0.5 \mathrm{~cm}$ thick coating of oil on the channel walls actually inhibits channel collapse. The durability of the oil coating is especially noticeable where sediment has been eroded from under the oil drape, yet the hardened oil coating remains intact (Fig. 9C). This is distinctly different than observed at the heavily oiled, Ile Grande marsh 


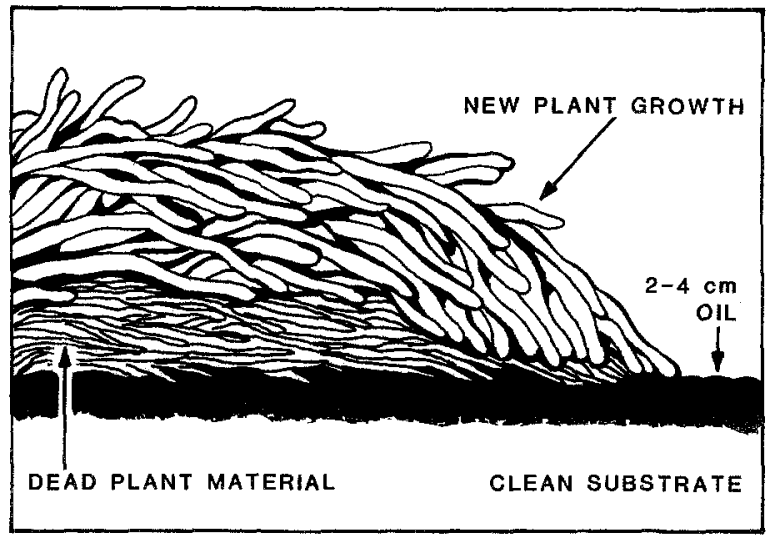

Fig. 10 Illustration of Salicornia growth over thick oil deposits. The roots of living Salicornia extend only into previously killed plant material and not directly into the oil. The oil in this area is still soft and mousse-like in consistency.

after the AMOCO CADIZ oil spill where extensive channel widening was caused by the loss of living, rooted vegetation to bind the channel wall sediments (Gundlach et al., 1981). Differences are based on the lack of hardened oil along the chanels at Ile Grande.

\section{DISCUSSION}

The continued persistence of oil within Strait of Magellan environments necessitates a lengthening of the predicted duration of oil spilled in similar coastal sites. After the $1975 / 76$ surveys, it was felt that oil would remain only two to three years in mixed sand and gravel beaches, and up to 20 years in Espora marsh. Now that almost seven years have passed since the spill and oil remains in many of the previously heavily oiled areas, it is time to increase the predicted duration of spilled oil on low wave-energy, mixed sand and gravel beaches to some 15 years. Where wave action is very limited, as along the First Narrows, persistence may exceed 30 years on this same beach type. Within sheltered tidal flats, there is little reason to believe that oil will ever be physically removed from this environment without complete erosion of the entire site (e.g. channel migration). Similar sentiments can also be expressed for the heavily oiled marsh at Espora. With less than one percent new growth at the site and little evidence of oil weathering, oil may persist for more than 100 years. Even if Salicornia overgrows the entire site, oil would still persist just underneath the plants' root structure.

\section{ACKNOWLEDGEMENTS}

We would especially like to thank Leonardo Guzman of the Instituto de la Patagonia for assistance with the logistical aspects of this study. While in the field Gaston Gaete Coddou greatly increased the effectiveness of our limited time at the study site. Living facilities were graciously supplied by ENAP, the Chilean national petroleum company. Financial support was provided by the LongRange Effects Research Program of the National Oceanic and Atmospheric Administration, Office of Marine Pollution Assessment.

\section{REFERENCES}

J. M. Baker, I. Campodonico, L. Guzman, J. J. Texera, B. Texera, C. Venegas and A. Sanhueza, 'An oil spill in the Straits of Magellan', in Marine Ecology and Oil Pollution, (J. M. Baker ed.), Halstead Press, N.Y., Chapter 18, pp. 441-471 (1976).

A. E. Blount, Two years after the METULA oil spill, Strait of Magellan, Chile; oil interaction with coastal environments, Tech. Rept. No. CRD-16, Coastal Res. Div., Dept. Geol., Univ. South Carolina, Columbia, 1978, 207 pp.

R. R. Colewell, A. L. Milles, J. D. Walker, P. Garcia-Tello and V. Compos-P., 'Microbial ecology studies of the METULA spill in the Strait of Magellan', J. Fish. Res. Bd. Canada 35(5), 573-580 (1978). O. Dollenz, 'Estado de la flora vascular en Puerto Espora, Tierra del Fuego, contaminada por el petro- leo del B/T METULA. I. Reconocimiento de la entrada de mar Noroeste', Anales del Instituto de la Patagonia, Punta Arenas, Chile 8, 251-261 (1977).

O. Dollenz, 'Estado de la flora vascular en Puerto Espora, Tierra del Fuego, contaminada por el petroleo del B/T METULA, 1978; Anales del Instituto de la Patagonia, Punta Arenas, Chile 9 133-139 (1978). E. R. Gundlach, S. Berne, L. D'Ozouville and J. A. Topinka, 'Shoreline oil two years after AMOCO CADIZ: new complications from TANIO', in Proc. 1981 Oil Spill Conf., API Publ. No. 4334, Wash. DC 1981, pp. 525-534.

C. G. Gunnerson and G. Peter, The METULA oil spill. NOAA/MESA, Environ. Res. Lab., USGPO, Wash., DC, 1976, 37 pp.

L. Guzman and I. Campodonico, 'Studies after the 
METULA oil spill in the Strait of Magellan, Chile; Petroleum and the Marine Environment, Graham \& Trotman, London, 1980, pp. 363-377.

R. W. Hann, Jr, Oil pollution from the tanker $M E-$ TULA, Rept. to US Coast Guard, Texas A \& M Univ., Civil Eng. Dept., College Station, Texas, 1974, $61 \mathrm{pp}$.

R. W. Hann, Jr, Follow-up field survey of the oil pollution from the tanker METULA, Rept. to US Coast Guard, Texas A \& M Univ., Civil Eng. Dept., College Station, $1975,57 \mathrm{pp}$.

R. W. Hann Jr, and H. N. Young, Fate of oil spilled from the supertanker METULA, Final Rept. to US Coast Guard, Texas A \& M Univ., Civil Eng. Dept., College Station, Texas, 1979, $149 \mathrm{pp}$.

M. O. Hayes and E. R. Gundlach, Coastal morphology and sedimentation of the METULA oil spill site in the Strait of Magellan, Rept. to Natl. Sci. Found., Coastal Res. Div., Dept. Geol., Univ. South Carolina, Columbia, 1975, $103 \mathrm{pp}$.

D. Lanfranco 'Situacion de la fauna entomologica en
Puerto Espora, Tierra del Fuego, luego de la contaminacion provocada por el petroleo del B/T METULA. I. Entomofauna suelo-superficial, Anales de Instituto de la Patagonia, Punta Arenas, Chile 10, 209-218 (1979).

S. P. Langley and G. Lembeye, 'Algunos antecedentes sobre el macrobentos, granulometria y contenido de petroleo en los sedimentos de dos entradas de mar en Puerto Espora (Tierra del Fuego) contaminados por el derrame del B/T METULA', Anales del Instituto de la Patagonia, Punta Arenas, Chile 8, 375-388 (1977).

E. Pisano, 'Contaminacion por petroleo del $\mathrm{B} / \mathrm{T} \mathrm{ME}-$ TULA en vegetacion fanerogamica litoral; observaciones preliminares' Anales del Instituto de la Patagonia, Punta Arenas, Chile 7, 139-153 (1976).

D. Straughan, 'Biological studies of the METULA oil spill', in Proc. Conf. on Assessment of Ecological Impacts of Oil Spills, Amer. Inst. Biol. Sci., Arlington, Vir., 1978, pp. 364-377. 